http://www.pakjas.com.pk

\title{
Appraisal of quantitative and qualitative losses in six rice genotypes caused by Trogoderma granarium (Everts) and Rhyzopertha dominica (F.)
}

\author{
Awais Ali Chatha ${ }^{1, *}$, Muhammad Asrar ${ }^{1}$, Syed Makhdoom Hussain ${ }^{1}$, Muhammad Kashif Zahoor ${ }^{1}$ and \\ Philip G. Koehler ${ }^{2}$
}

${ }^{1}$ Department of Zoology, Government College University, Faisalabad, Pakistan; ${ }^{2}$ Department of Entomology and Nematology, University of Florida, USA

*Corresponding author's e-mail: awais.chatha@ufl.edu

\begin{abstract}
The present study was conducted to probe out the nutritive losses caused by Rhyzopertha dominica (F.) and Trogoderma granarium (Everts) were quantified in six rice genotypes (KSK-434, KSK-282, Irri-6, Shaheen basmati, Basmati 385 and Chenab basmati). Percent crude protein, ash and moisture content were measured for qualitative losses, while for quantitative losses, frass weight and weight loss were examined after infestation period of 90 days of. Highest weight losses (25.76\%) and (15.37\%) were observed in KSK-434 by infestation of $R$. dominica and $T$. granarium, respectively, compared with un-infested grains after a storage period of 90 days. Highest frass weight $(8.57 \mathrm{~g})$ was recorded for KSK-434 while relatively low frass weight $(4.16 \mathrm{~g})$ was recorded for Basmati 385 by infestation of $R$. dominica. Relatively low frass weights of $5.67,4.46$ and $4.01 \mathrm{~g}$ were recorded in KSK-434, Chenab basmati and Shaheen basmati, respectively by attack of $T$. granarium. Highest percentage moisture values (14.03 and 11.24\%) were recorded for KSK-434 by infestations of both test insects compared to non-infested (controls). Percent crude protein was decreased (from $6.97 \%$ to the $4.92 \%$ ) due to infestation of $R$. dominica values by strain were KSK-434 (4.54\%), Shaheen basmati (4.89\%) and chenab basmati (4.92\%). In the case of $T$. granarium infestation, almost all the varieties sustained the low protein contents except KSK-434 (5.02\%) and Basmiti 385 (5.17\%) and Shaheen basmati, protein contents loss comparable to non-infested control (7.09\%). Ash content was high in genotype KSK$282(0.68 \%)$ compared to control. KSK-434 and Chenab basmati had relatively low ash percentage due to high infestation of $T$. granarium. $R$. dominica attack produced the highest percent ash content $(0.66 \%)$ in KSK-282 and the least $(0.44 \%)$ in KSK434. The tested rice genotypes were more susceptible to $R$. dominica than $T$. granarium among the different genotypes of selected cereals.
\end{abstract}

Keywords: Crud ash, highest, moisture content, stored grains, weight losses.

\section{INTRODUCTION}

Cereals are the nutritional backbone of humans with $1 / 4$ of the total energy acquired from the cereals (Bartlomiej et al., 2012). Wheat is grown extensively in many parts of the world and is used extensively as a raw material in dried foodstuffs (Anon., 2011). Rice, Oryza sativa L. is the main cereal crops in Pakistan and many other Asian countries such as Bangladesh, Indonesia and Thailand. These Cereals provide essential amino acids like threonine, isoleucine, lysine and tryptophan) (Bartlomiej et al., 2012) and are important for human nutrition.

During proper rice storage, few living agents (e.g., insect pests, bacteria and fungi) can cause deterioration of grain quality. When living agents occur, they can damage the rice grains, lower their palatability, reduce value of bakery products and make them unfit for export (Shafique and Chaudry, 2007). Stored grains are vulnerable to attack by various primary and secondary insects, pests like Sitophilus granaries (L.), Trogoderma granarium (Everts), Sitophilus oryzae (L.), Tribolium castaneum (Herbst), Plodia interpunctata (Hubner), Corcyra cephalonica (Stainton) and Sitotroga cerelella (Olivier). T. granarium is the most important insect pest of stored rice. Adults usually do not feed but larvae of the insect are voracious feeders (Athanassiou $e t$ al., 2019). Larvae start feeding from one end of the kernel, eventually damage the whole kernel and creating large amounts of frass (Shafique and Ahmad, 2003; Parashar, 2006). Losses to grains during storage by insect infestations are noticeable, causing up to $20 \%$ damage to stored rice in

Chatha, A.A., M. Asrar, S.M. Hussain, M.K. Zahoor and P.G. Koehler.2021. Appraisal of quantitative and qualitative losses in six rice genotypes caused by Trogoderma granarium (Everts) and Rhyzopertha dominica (F.). Pak. J. Agri. Sci. 58:1185-1189.

[Received 17 Feb 2021; Accepted 27 Jul 2021; Published (online) 21 Sep 2021] 
developing countries and up to $9 \%$ in developed countries (Phillips and Throne, 2010). Insect pests not only directly consume stored food items but also contaminate the grain with insect cadavers, frass and exuviae which reduces the quality of grains commodities (Dubey et al., 2008).

Of all the types of stored grain pests, insects significantly have the most important effect on quantitative as well as qualitative losses. Similar to other developing countries, storage losses in Pakistan by stored insect pests are 5-10\% (Ahmad, 1980). These losses are mainly caused by infestations of $R$. dominica, $T$. granarium, S. cerealella, $T$. castaneum and S. oryzae (Lowe et al., 2000). Yearly post-harvest grain losses are around 5-10\% for O. sativa in Pakistan (Ahmad, 1994). Because of this important infestation of stored grain, there is a need to evaluate storage losses and determine the value of various insect pest management strategies. Therefore, the present study was executed to evaluate quantitative and qualitative losses in six rice varieties to determine their relative resistance against $R$. dominica and T. granarium.

\section{MATERIALS AND METHODS}

Research was conducted in the Department of Zoology, Government College University Faisalabad and Grain Research, Training and Storage Management Cell, Department of Entomology, University of Agriculture Faisalabad, Pakistan to evaluate the relative resistance of six advanced rice genotypes (KSK-434, KSK-282, Irri-6, Shaheen basmati, Basmati 385 and Chenab basmati) against $T$. granarium and $T$. castaneum during storage period of 90 days. The genotypes of rice were obtained from Rice Research Station, Kalashahkaku. In the laboratory, rice grains were washed and then air dried to obtain moisture contents $12 \%$. Seeds were then sterilized to remove any previous insect infestation prior to beginning the research work. Samples of each rice variety weighed $200 \mathrm{~g}$ and were placed into separate plastic jars $(250 \mathrm{ml})$. For each insect pest, $3^{\text {rd }}$ instar larvae (n $=50$ ) were removed from insect cultures and placed into jars containing seeds. Treatments were replicated three times using a completely randomized design (CRD). All jars were placed at optimum growth conditions of $30^{\circ} \mathrm{C}$ and $65 \pm 5 \%$ R.H.

Physical Parameters: Physical parameters measured were percent insect damaged and undamaged grains, percent weight loss and insect frass weight. Grain frass (the powdery material collected at the bottom of the jar in the form of insect feces, debris and broken food particles known) was weighed after 90 days.

After separating insect frass from rice at $90 \mathrm{~d}$, a rice sample (20 g) was taken from every replication of the respective variety of each genotype of rice. Grains were separated and counted to calculate percent insect damaged and undamaged grains and percent weight loss using the following equations:

$$
\text { Insect damage grains }(\%)=\frac{\mathrm{DG}}{\text { Total grains }} \times 100
$$

Where DG= Damaged grains

$$
\text { Insect undamage grains }(\%)=\frac{\mathrm{UDG}}{\text { Total grains }} \times 100
$$

Where UDG $=$ Undamaged grains

$$
\text { Weight loss }(\%)=\frac{(\mathrm{UNd})-(\mathrm{DNu})}{\mathrm{U}(\mathrm{Nd}+\mathrm{Nu})} \times 100
$$

Where $\mathrm{U}=$ weight of undamaged grains, $\mathrm{Nd}=$ number of damaged grains, $\mathrm{D}=$ weight of damage grains and $\mathrm{Nu}=$ number of undamaged grains (Gwinner et al., 1996).

Qualitative parameters: Qualitative changes due to the feeding of $T$. granarium and $T$. castaneum larvae were evaluated by determining ash content and crude protein by means of AOAC and ICC procedures (Anon., 2000). For this, $100 \mathrm{~g}$ screened samples of each variety of rice were used to find out the contents of desired substances. Chemical analysis were done in Food Science and Technology Laboratory in University of Agriculture Faisalabad.

Chemical analysis: Analysis determined dry weight basis of crude ash, \% moisture and crude protein.

Moisture content was determined by AACC (2000) technique No. 44-19. Milled rice ( $3 \mathrm{~g}$ ) was placed in a pre-warmed and weighed metal dish and dried at $130^{\circ} \mathrm{C}$ in a hot air oven for $2 \mathrm{~h}$. Weight loss was defined as percentage of moisture content of rice.

$$
\text { Percent MC }=\frac{(\mathrm{W} 1-\mathrm{W} 2)}{\text { Weight of sample }} \times 100
$$

Where $\mathrm{MC}=$ Moisture content; $\mathrm{W} 1=$ rice sample weight and metallic dish prior to heating; $\mathrm{W} 2=$ rice sample weight and metallic dish after heating.

For percent ash analysis, a $5 \mathrm{~g}$ sample (well sorted) was weighed into a wider shallow dish that had been heat dried, cooled in desiccators and weighed quickly after reaching room temperature. The resulting sample was then heated in a furnace at $550^{\circ} \mathrm{C}$ for a period of $4 \mathrm{~h}$. Until reduced to a light gray ash residue which was refrigerated in a desiccator. The weight of the ash residue was then measured at room temperature following AOAC Technique No. 923.03 and the formula;

$$
\text { Percent Ash }=\frac{\text { Weight of residue }}{\text { Weight of sample }} \times 100
$$

Nitrogen containing compounds were determined by oxidizing the organic material of the tested sample with concentrated sulfuric acid in the presence of a selenium catalyst. The resulting product, (NH4)2SO4, was treated with alkali free ammonia that was distilled and titrated AOAC Technique No. 979.09 (Anon., 2000). Crude protein (\%) was determined by multiplying the entire amount of nitrogencontaining compounds by a factor of 6.5 (for rice sample).

Statistical Analysis: The experimental design was a completely Randomized Design (CRD) replicated three times. ANOVAs were done with 8.0 statistical software (StatSoft, Inc., 2008), and means were separated with Tukey's HSD test $(p \leq 0.05)$. 


\section{RESULTS AND DISCUSSION}

Physical analysis: Percent weight losses in different rice genotypes by the infestation of the two stored grain insect pests (Fig.1) showed significant of the main effect (insect species) at $\mathrm{P} \leq 0.05$. In case of $R$. dominica infestation, means of Genotype KSK-434 and Basmati-385 were significantly different from each other. While in case of $T$. granarium attack, mean weight loss for KSK-434 was significantly different from the rest of the rice genotypes. Highest weight loss $(25.76 \%)$ was recorded in case of KSK-434 followed Irri$6(18.57 \%)$, Chenab basmati (14.61\%) compared to the control (4.16\%). While highest weight loss (15.37\%) in KSK434 was recorded in grains attacked by T.granarium compared to control $(6.03 \%)$.

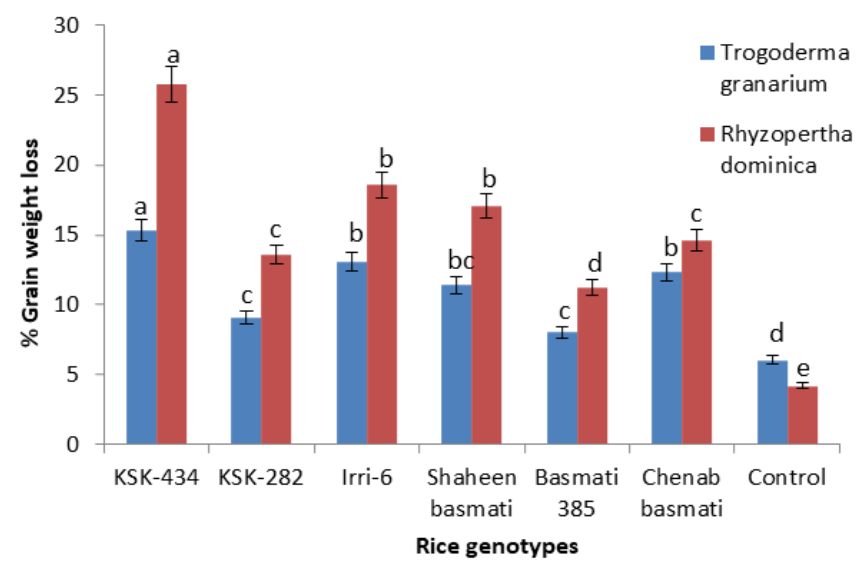

Figure 1. Comparison of percent weight losses in six genotypes of rice by infestation of Trogoderma granarium and Rhyzopertha dominica after 90 days. *Means with the same letters (top of the column) are not significant at $\mathrm{P} \leq 0.05$.

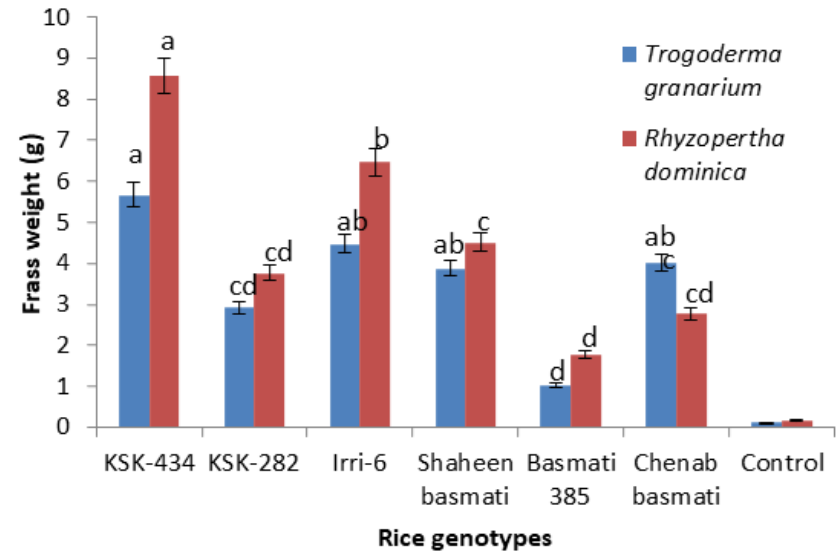

Figure 2. Comparison of percent frass weight $(\mathrm{g})$ in six genotypes of rice by infestation of Trogoderma granarium and Rhyzopertha dominica. *Means followed by the same letters (in column) are not significant at $\mathrm{P} \leq 0.05$.
Mean percent frass weight in $R$. domonica infestation of rice genotypes KSK-434, Irri-6, Shaheen basmati and basmati385 (Fig. 2) were statistically different from each other at $\mathrm{P} \leq 0.05$. While $T$. granarium attack mean percent frass weight in KSK-434, Basmati-385 were found statistically different from each other. Comparatively higher percent frass weight $(8.57,6.46,4.51$ and $4.16 \mathrm{~g})$ were recorded in case of KSK434, Irri-6, Shaheen basmati and Basmati 385, respectively by infestation of $R$. dominica after an infestation period of 90 days (Fig. 2). Relatively low values of frass weight 5.67, 4.46 and $4.01 \mathrm{~g}$ were recorded in KSK-434, Chenab basmati and Shaheen basmati by attack of $T$. granarium.

Qualitative analysis: Chemical analysis

Table 3. Mean moisture $(\%)$ in six genotypes of rice attacked by Trogoderma granarium and Rhyzopertha dominica.

\begin{tabular}{lcc}
\hline Treatments & $\begin{array}{c}\text { Trogoderma } \\
\text { granarium }\end{array}$ & $\begin{array}{c}\text { Rhyzopertha } \\
\text { dominica }\end{array}$ \\
\hline KSK-434 & $11.24 \pm 0.10 \mathrm{~b}$ & $14.02 \pm 0.12 \mathrm{a}$ \\
KSK-282 & $9.56 \pm 0.10 \mathrm{bcd}$ & $11.10 \pm 0.14 \mathrm{~b}$ \\
Irri-6 & $8.01 \pm 0.12 \mathrm{def}$ & $9.18 \pm 0.11 \mathrm{bcd}$ \\
Shaheen basmati & $9.87 \pm 0.11 \mathrm{bcd}$ & $11.79 \pm 0.16 \mathrm{bc}$ \\
Basmati 385 & $8.62 \pm 0.13 \mathrm{~d}$ & $11.14 \pm 0.14 \mathrm{bc}$ \\
Chenab basmati & $10.82 \pm 0.10 \mathrm{bc}$ & $12.17 \pm 0.17 \mathrm{~b}$ \\
Control & $7.03 \pm 0.15 \mathrm{f}$ & $5.70 \pm 0.18 \mathrm{f}$ \\
\hline
\end{tabular}

*Means followed by the same letters (in column) are not significant at $\mathrm{P} \leq 0.05$.

Voracious feeding by both test insect pests was encouraged as a result of elevated moisture contents in rice grains (Table 3 ). In case of $R$. dominica attack, means moisture for KSK-434 and KSK-282 were statistically different from each other at $\mathrm{P} \leq 0.05$. While means for Basmati 385 and KSK-434 were also statistically different. Moisture contents in KSK-434 attacked by $T$. granarium and $R$. dominica (14.02 and $11.24 \%$ respectively) were recorded as highest due to increased respiration of the insects and biochemical changes induced by the infestations of both test insects compared to control.

Table 4. Mean percent of crude ash in six rice genotypes infested by Trogoderma granarium and Rhyzopertha dominica.

\begin{tabular}{lll}
\hline Treatments & $\begin{array}{c}\text { Trogoderma } \\
\text { granarium }\end{array}$ & $\begin{array}{c}\text { Rhyzopertha } \\
\text { dominica }\end{array}$ \\
\hline KSK-434 & $0.48 \pm 0.32 \mathrm{~d}$ & $0.44 \pm 0.26 \mathrm{~d}$ \\
KSK-282 & $0.68 \pm 0.22 \mathrm{~b}$ & $0.66 \pm 0.04 \mathrm{a}$ \\
Irri-6 & $0.67 \pm 0.26 \mathrm{~b}$ & $0.59 \pm 0.03 \mathrm{ab}$ \\
Shaheen basmati & $0.64 \pm 0.25 \mathrm{bc}$ & $0.62 \pm 0.03 \mathrm{bc}$ \\
Basmati 385 & $0.59 \pm 0.28 \mathrm{ab}$ & $0.54 \pm 0.04 \mathrm{c}$ \\
Chenab basmati & $0.55 \pm 0.25 \mathrm{c}$ & $0.50 \pm 0.04 \mathrm{~cd}$ \\
Control & $0.73 \pm 0.25 \mathrm{a}$ & $0.69 \pm 0.03 \mathrm{ab}$ \\
\hline
\end{tabular}

*Means followed by the same letters (in column) are not significant at $\mathrm{P} \leq 0.05$. 
For mean crude ash means (table 4), KSK-282, Basmati-385 and KSK-434 were statistically different from each other at $\mathrm{P} \leq 0.05$ when attacked by $R$. dominica, while crude ash means of Chenab basmati and KSK-4344 were statistically different from each other (when the infesting insect was T.granarium). KSK-434 and Chenab basmati displayed relatively low ash contents due to high infestation of T. granarium. In case of $R$. dominica attack, the highest mean percent ash content $(0.66 \%)$ was observed in KSK-282 while relatively low percent ash content $(0.44 \%)$ was recorded in KSK-434.

Table 5. Mean percent crude protein (\%) in six rice genotypes infested by Trogoderma granarium and Rhyzopertha dominica.

\begin{tabular}{llc}
\hline Treatments & $\begin{array}{c}\text { Trogoderma } \\
\text { granarium }\end{array}$ & $\begin{array}{c}\text { Rhyzopertha } \\
\text { dominica }\end{array}$ \\
\hline KSK-434 & $5.02 \pm 0.32 \mathrm{~cd}$ & $4.54 \pm 0.26 \mathrm{~d}$ \\
KSK-282 & $6.80 \pm 0.22 \mathrm{ab}$ & $6.62 \pm 0.25 \mathrm{~b}$ \\
Irri-6 & $6.07 \pm 0.26 \mathrm{~b}$ & $5.57 \pm 0.27 \mathrm{c}$ \\
Shaheen basmati & $5.38 \pm 0.25 \mathrm{c}$ & $4.89 \pm 0.22 \mathrm{~d}$ \\
Basmati 385 & $5.17 \pm 0.28 \mathrm{~cd}$ & $6.35 \pm 0.25 \mathrm{~b}$ \\
Chenab basmati & $6.57 \pm 0.25 \mathrm{~b}$ & $4.92 \pm 0.20 \mathrm{~d}$ \\
Control & $7.09 \pm 0.25 \mathrm{a}$ & $6.97 \pm 0.21 \mathrm{ab}$ \\
\hline
\end{tabular}

*Means followed by the same letters (in column) are not significant at $\mathrm{P} \leq 0.05$.

Changes in percent crude protein due to the infestation of the both stored grains insects are presented in table 5. Crude protein means of Chenab basmati and Shaheen basmati were statistically different from each other at $\mathrm{P} \leq 0.05$ (in $T$. granarium attacked rice genotypes). Almost all the varieties sustained the protein contents except KSK-434 (5.02\%) and Basmiti $385(5.2 \%)$ compared to control. While in $R$. dominica attacked rice genotypes, Crude protein mean of Irri6 was found statistically different from rest of the rice genotypes. KSK-434 (4.54\%), Shaheen basmati (4.89\%) and chenab basmati $(4.92 \%)$ retained relatively minimum crude protein contents to respective control $(7.0 \%)$.

\section{DISCUSSION}

Our research trials demonstrated changing degree of resistance in different rice genotypes against the attack of $T$. granarium in the storage situations. Our findings parallel those by Ali et al. (2009) who assessed the resistance level in various genotypes of wheat attacked by $T$. castaneum. Two parameters (quantitative and qualitative losses are applied to test the verities of rice and increase the population density were studied to evaluate the relative susceptibility or resistance (Shafique and Chaudry, 2007). Our study showed that none of rice genotype was completely resistance to $T$. granarium and $R$. dominica infestation. These results are similar to Ali et al. (2016). Our result are in parallel with the results of previous scientist who concluded that each genotype of any cereal responds in a different way to the stored grain insect pest (Qurban et al., 2016). Previous study (Shafique and Chaudry, 2007) showed that the low insect population and low weight loss of grain can be related to the grain resistance against insects. So, based on our data, we can conclude that Basmati 385 was the most resistant verity while the KSK 434 was the most susceptible variety against $T$. granarium and $R$. dominica. Arthur et al. (2007) appraised the effect of insect pest attack on various cultivars grown at dissimilar sites and explored noteworthy association among long-grain cultivars within 2 of the 3 sites against insect proliferation and attack. Pittendrigh et al. (1997) examined the reaction of relative humidity on the larval growth of $S$. oryzae raised on corn seeds to evaluate the superfluous molts. They recorded lower number of the molts (4) at 70\% R.H and 5 extra molts at low humidity $40 \%$ R.H. Chanbang et al. (2008) examined the vulnerability of rice varieties owing to the hardness of the kernel and determined that hardiness of the kernel is straightly linked with insect pest attack. Michael and Riggio (2002) conducted research to check the occurrence of vulnerability/resistance in some rice lines and variation in vulnerability comparative with two marketable genotypes. After completion of the research trial they determined that there were few biochemical or morphological processes of resistance to the paddy water weevil in the tested lines. Lawrence (1990) examined remarkable loss in stored paddy and offspring development of $S$. oryzae and $R$. dominica for the period of threshing certain varieties of cereals. Our result showed that highest weight loss was due to high moisture contents. These finding are similar with previous study (Khaliq et al., 2013).

Our research trials demonstrated an influence of temperature on grain damage because of quick development of insect pests, as described by Shafique and Chaudry (2003), who evaluated similar outcomes in production of insect pest offspring. Findings by Khattak et al. (2000) showed that varieties of rice displayed noteworthy reaction to the emergence of $S$. oryzae adults, and analogous outcomes were documented by other workers (Shafique and Chaudry; 2007). Togola et al. (2013) described that insect pests on stored commodities caused losses to rice in storage structures and induced quantitative as well as qualitative losses.

Conclusion: From the above findings it is inferred that both the insect pests can cause significant quantitative as well as qualitative losses in stored commodities. KSK-434 was the most susceptible variety for both the insects while Basmati 385 was the least susceptible one. So, strict measures should be taken regarding management of these two insect pests.

\section{REFERENCES}

Ahmad, F.U., 1980. Insect pest and their control in stored wheat. Pakistan Agriculture. 3:9-10. 
Ahmad, M., 1994. From the desk of editor-in-chief. Grain storage management newsletter. 2:1-5.

Ali, A., M. Sarwar, S. Khanzada and G.H. Abro. 2009. Reaction of certain wheat varieties to the action of red flour beetle, Tribolium castaneum (Herbst) (Coleoptera) under insectary conditions. Pak. J. Zool. 41:51-56.

Anon., 2000. Approved methods of American Association of Cereal Chemists. The American Association of Cereal Chemists. Inc., Saint Paul, Minnesota, USA.

Anon., 2011. Global cereal supply and demand brief. Available online at http:// faostat.fao.org (Acessed on. 27-3-2012).

Arthur, F., R. Bautista and T.J. Siebenmorgen. 2007. Influence of growing location and cultivar on Rhyzopertha dominica (Coleoptera: Bostrichidae) and Sitophilus oryzae (Coleoptera: Curculionidae) infestation of rough rice. Insect Sci. 14:231-239.

Athanassiou, G.C., T.W. Phillips and W. Wakil. 2019. Biology and Control of the Khapra Beetle, Trogoderma granarium, a Major Quarantine Threat to Global Food Security. Ann. Rev. Entomol. 64:131-148.

Bartłomiej, S., R.K. Justyna and N. Ewa. 2012. Bioactive compounds in cereal grains-occurrence, structure, technological significance and nutritional benefits-a review. Food Sci. Tech. Inter. 18:559-568.

Dubey N.K., B. Srivastava and A. Kumar. 2008. Current status of plant products as botanical pesticides in storage pest management, J. Biopesticide. 2:182-186.

Gwinner, J., R. Harnisch and O. Muck. 1996. Manual on the prevention of post-harvest seed losses, post-harvest project, GTZ, D-2000, Hamburg, FRG. pp. 294.

Khaliq, A., M. ul-Hasan and F.Z. Ahmad. 2013. Varietal screening and development of rice weevil, Sitophilus oryzae (L.) in advanced rice genotypes at different temperatures. Int. J. Biosci. 3:287-292.

Khattak, S.U., S. Kama, K. Amanullah, S. Ahmad, A.U. Khan and A. Jabbar. 2000. Appraisal of rainfed wheat lines against khapra beetle, Trogoderma granarium (Evert.). Pak. J. Zool. 32:131-134.

Lawrence, E.W. and J.R. Pedersen. 1990. Effect of threshing different sorghum cultivars on Sitotroga cerealella (Oliv.) and Sitophilus oryzae (L.) (Lepidoptera: Gelechiidae and Coleoptera: Curculionidae). J. Stored Prod. Res. 26:89-96.
Lowe, S.M., S. Browne, S. Boudjelas and M. DePoorter. 2000. 100 of the World's Worst Invasive Alien Species: A selection from the Global Invasive Species Database. Invasive Species Specialist Group, World Conservation Union (IUCN). Available online at www.issg.Org/booklet.

Michael, J.S. and M.R. Riggio. 2002. Variation in susceptibility of rice lines to infestation by the rice water weevil (Coleoptera: Curculionidae). J. Agric. Urban Entomol.19:205-216.

Parashar, M.P. 2006. Post-harvest profile of black gram. Govt. India, Ministry of Agric. Deptt. Agric. and Coop. Directorate of Marketing and Inspection, Nagpur440001.

Phillips, T.W. and J.E. Throne. 2010. Biorational approaches to managing stored-product insects. Ann. Rev. Entomol. 55:375-397.

Pittendrigh, B.R., J.E. Huesing, R.E. Shade and L.L. Murdock. 1997. Monitoring of rice weevil, Sitophilus oryzae, feeding behavior in maize seeds and the occurence of supernumerary molts in low humidity conditions. Entomol. Experiment. Applicata. 83:225231.

Qurban, A., M. ul Hasan, M. Sagheer, M.H. Ranjha and M. Shahbaz. 2016. Appraisal of quantitative losses caused by Trogoderma granarium (Everts) and Tribolium castaneum (Herbst) in different genotypes of wheat, rice and maize during storage. J. Appl. Biol. Sci. 10:8-14.

Shafique M. and A. Ahmad. 2003. Susceptibility of milled rice genotypes to Angoumois grain moth. SAARC J. Agric. 1:193-197.

Shafique, M. and M. A. Chaudry. 2007a. Screening of rice genotypes for resistance to storage insects. Pak. J. Zool. 29:19-22.

Shafique M. and M.A. Chaudry. 2007b - Susceptibility of maize grain to storage insects. Pak. J. Zool. 39:77-81.

StatSoft, Inc. 2008. STATISTICA (Data Analysis Software System), version 8.0. www.statsoft.com.

Togola, A., P.A. Seck, I.A. Glitho, A. Diagne, C. Adda, A. Toure and F.E. Nwilene. 2013. Economic Losses from Insect Pest Infestation on Rice Stored on-farm in Benin. J. Appl. Sci. 13:278-285. 